\title{
MARINE CONSERVATION IN THE REPUBLIC OF SOUTH AFRICA WITH SPECIAL REFERENCE TO MARINE PARKS AND RESERVES
}

\section{G A ROBINSON}

\author{
Park Warden: Tsitsikama Forest and Coastal National Parks \\ P O Storms River \\ 6308
}

\section{Introduction}

Conservation in the Republic of South Africa (RSA) is dominated by big game and terrestrial reserves. Protecting these, have been in existence for many years. Recently Man has turned his attention more and more to the sea and due to adverse effects of pollution, over-exploitation and habitat destruction the marine environment is threatened. However, conservationists have learnt lessons about both terrestrial and marine ecosystem-destruction and are now demanding with increasing persistence the establishment of marine parks and reserves. It is therefore not surprising that the IUCN's marine conservation programme, is to be given special emphasis during the two-year period, 1977 and 1978. With the establishment of a ministerial committee to investigate marine parks and reserves South Africa has not lagged behind. The committee's objectives are to promote marine conservation by the probable establishment of a system of marine parks and reserves.

The RSA has an exceptionally long and beautiful coastline $(2961 \mathrm{~km})$. Its west coast is lapped by the cold Benguela Current which originates in the Antarctic and supports one of the most productive fisheries in the world. On the east coast the shores are bathed by a current which arises in the Indian ocean, the warm Agulhas Current, and gives a tropical flavour to the marine life along this coast. The intermediate region or "South Coast" lies between these two spheres of influences and has representatives of both warm water and cold water communities living side by side (Fig. 1). A wide spectrum of marine fauna and flora is therefore, encountered along the shores of South Africa.

\section{Marine Conservation in the past}

"Conservation" means the wise use of resources. In a sense, Man has conserved (used) the biological resources of the sea since prehistoric 


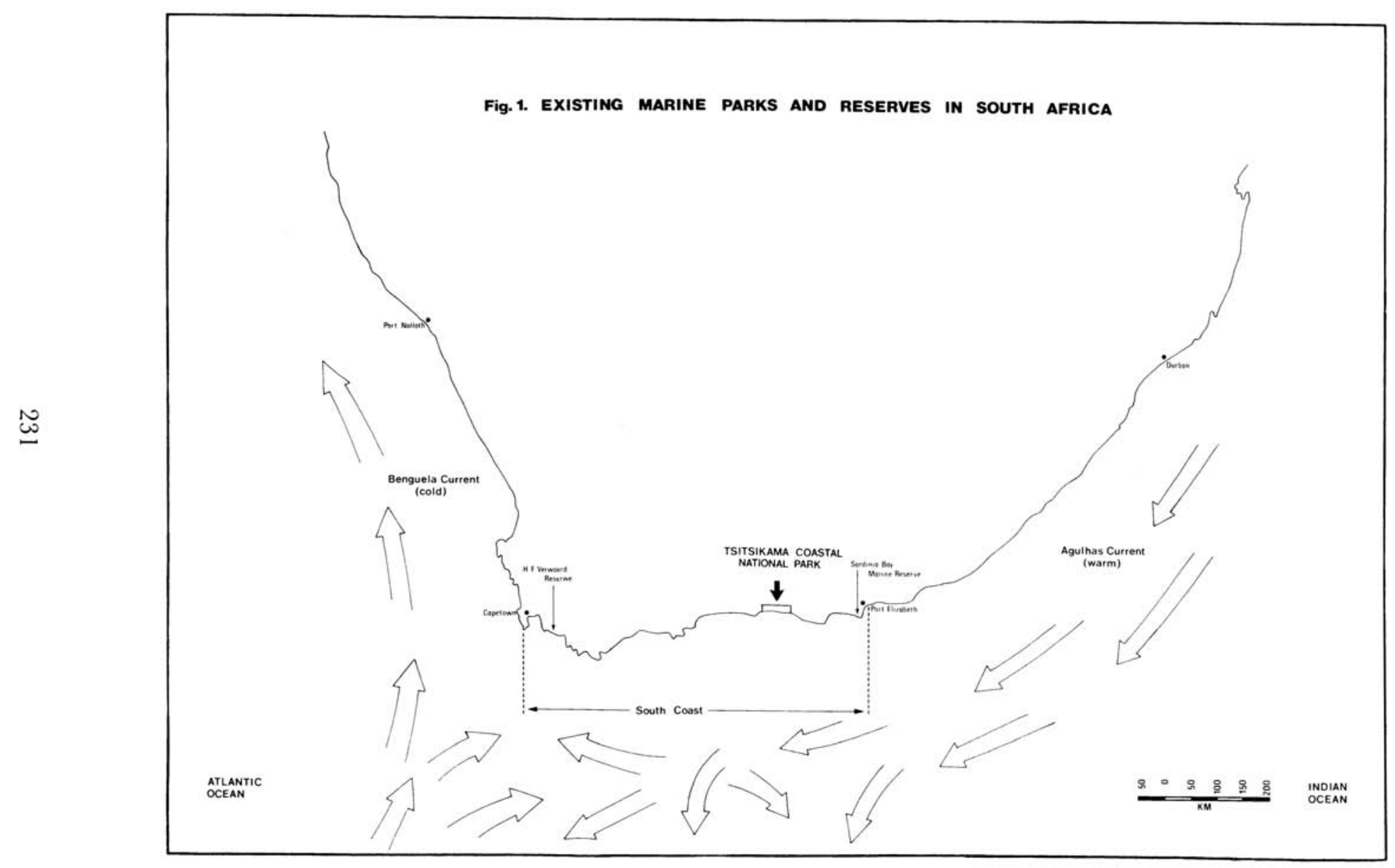


times. The normandic aborigines of the "South Coast", the Strandlopers, lived predominantly off the coast for thousands of years (Goodwin 1946). At first he collected mainly shellfish, as seen from the numerous Strandloper middens found along the coast, but he later built enclosures in the tidal zone in which he trapped fish. The enclosure is a stone wall built to such a height that the high tides will cover the enclosed area allowing fish to swim into it. As the tide recede, the fish were trapped and caught by hand. These aborigines probably conserved the marine resource more intelligently than our modern "civilized" society is apparently doing - he lived in harmony with his environment.

The value of the marine resources has in more recent times been recognised and the need for conservation fully appreciated. Biological and environmental research has been conducted by the Government in order to rationally exploit the fishery resources for many years. The regulatory agency in the earlier days was known as the Fisheries and Marine Biological Survey and was directed by Dr J F Gilchrist. Later this conservation agency became the Division of Sea Fisheries and has recently become the Sea Fisheries Branch. This Branch is responsible for regulating and conserving the exploitation of all marine biological resources with maximum sustainable yield as objective. The South African fishing industry is dominated by the pelagic west-coast fishery and the trawl fishery, but has also a valuable rock lobster fishery. It is, therefore, understandable that most of the research effort has been directed towards the species supporting these fisheries. Regulatory measures have been imposed on by the Branch to conserve the resources. These include the mesh-size of nets, gear to be used or not used, size limits, bag limits, closed seasons, quotas and sanctuaries. These sanctuaries were proclaimed to protect species such as rock lobsters, oysters and sea-horses. The Sea Fisheries Branch employs a large staff of inspectors at a considerable expense to enforce these regulations. This entails the inspection of catches, the hounding of rock lobster poachers and patrolling (both sea and land) of the sanctuaries.

\section{Marine Conservation at present}

In the past marine conservation went through two phases. The first, when man lived in harmony with the sea, he used the marine resources and they were conserved. But there was very little "intelligent" exploitation done. The second phase of marine conservation was the rational exploitation on a maximum sustainable yield basis. Here man used his intelligence to devise in some cases sophisticated, mathematical models whereby regulating his harvest.

Marine conservation implies the wise use of the marine resources and by this it does not only imply use in terms of human consumption. Wise use must also incorporate aesthetic and recreation values. The estab- 
lishment of marine parks and reserves is then the third phase of marine conservation.

Participants at the First World Conference on National Parks in Seattle Washington, in 1962, after discussing underwater preservation, passed Resolution No. 15 that stated:

"Whereas it is recognized that the oceans and their teeming life are subject to the same dangers of human interference and destruction as the land, that the sea and land are ecologically independent and indivisible, that population pressures will cause man to turn increasingly to the sea, and especially to the underwater scene, for recreation and spiritual refreshment, and that the preservation of unspoiled marine habitat is urgently needed for ethical and esthetic reasons, for the protection of rare species, for the replenishment of stocks and valuable food species, and for the provision of undisturbed area for scientific research.

The First World Conference on National Parks invites the governments of all those countries having marine frontiers, and other appropriate agencies, to examine as a matter of urgency the possibility of creating marine parks or reserves to defend underwater areas of special significance from all forms of human interference and further recommends the extension of existing national parks and equivalent reserves with shorelines, into the water to the ten fathom depth or the territorial limit or some other appropriate off-shore boundary."

This recommendation gave considerable momentum to the third phase of marine conservation and the establishment of several parks and reserves in various parts of the world resulted. During more recent years meetings such as the Second World Conference on National Parks in 1972, the International Conference on Marine Parks and Reserves in Tokyo 1975 and the 12th General Assembly of the IUCN, held in Zaire 1975 , have greatly emphasized the need for marine conservation and marine reserves.

Three out of 12 general resolutions passed at Kinshasa, Zaire in September 1975 by the general assembly related to marine conservation read as follows:

\section{Resolution number 2}

Calls on governments to establish marine parks and reserves of sufficient area to protect the vulnerable features of vulnerable marine habitats; and

Recommends to governments with terrestrial parks or reserves adjoining coastal areas of value for nature conservation that they extend the boundaries of those parks to include a marine component. 


\section{Resolution number 3}

Recommends that areas as large as possible of sea-grass, coral reefs and mangroves be set aside as reserves for research and the protection of life. Urges the coastal states with such habitats within their jurisdiction to evolve a policy to maintain their continued health and stability, and urges the research and monitoring programmes in such areas be strengthened or initiated to establish guidelines for their management.

\section{Resolution number 4}

Requests governments to take urgent steps to protect and manage key areas, large enough to form viable ecological limits, containing mangroves, salt marshes and related wet-lands together with adjacent estuarine waters as reserves for the preservation of these ecosystems and the species for which they provide habitat.

From the above it is transparently clear that internationally there is a growing concern regarding the state of the marine environment. There is a restless feeling amongst conservationists - time is running out.

\section{Threats to Marine Resources}

Why the haste to establish marine parks and reserves? The reason is that many marine species and habitats are today threatened. This is due to man's irrational approach to the conservation of these natural resources. We are all, by and large, fond of the coast but the sea or ocean appeals to but a few of us. Of these few, fewer still appreciate it as an environment. The ocean is valued as a resource to be exploited and misused. But let us look at the causes that threaten our marine environment. Foremost in most marine situations is pollution. From the earliest times, man has used the sea as a dumping place for his refuse. It was generally accepted to be a "bottomless pit". When our waste was still mostly organic matter, this dumping was of little consequence but now, with inorganic chemicals, pesticides, and radio-active wastes, they are not easily disposed of. There are some that become extremely concentrated in filter-feeding animals such as bivalves. Oysters are known to store contaminants in their tissues at concentrations 70000 times greater than in their surrounding water. Although these animals may themselves be in a healthy condition they can be lethal to animals feeding on them.

When one speaks of pollution, sewage and oil spillage is usually thought of. Pollution is not always unsightly, sticky or smelly. Nuclear power stations for instance pump heated effluent into the sea which can and do disrupt the marine environment.

Secondly, over-exploitation of these resources by fishermen can cause serious problems. It is hardly necessary to repeat the tragic history of the exploitation of the whales (Chapman 1971) to illustrate the illogical 


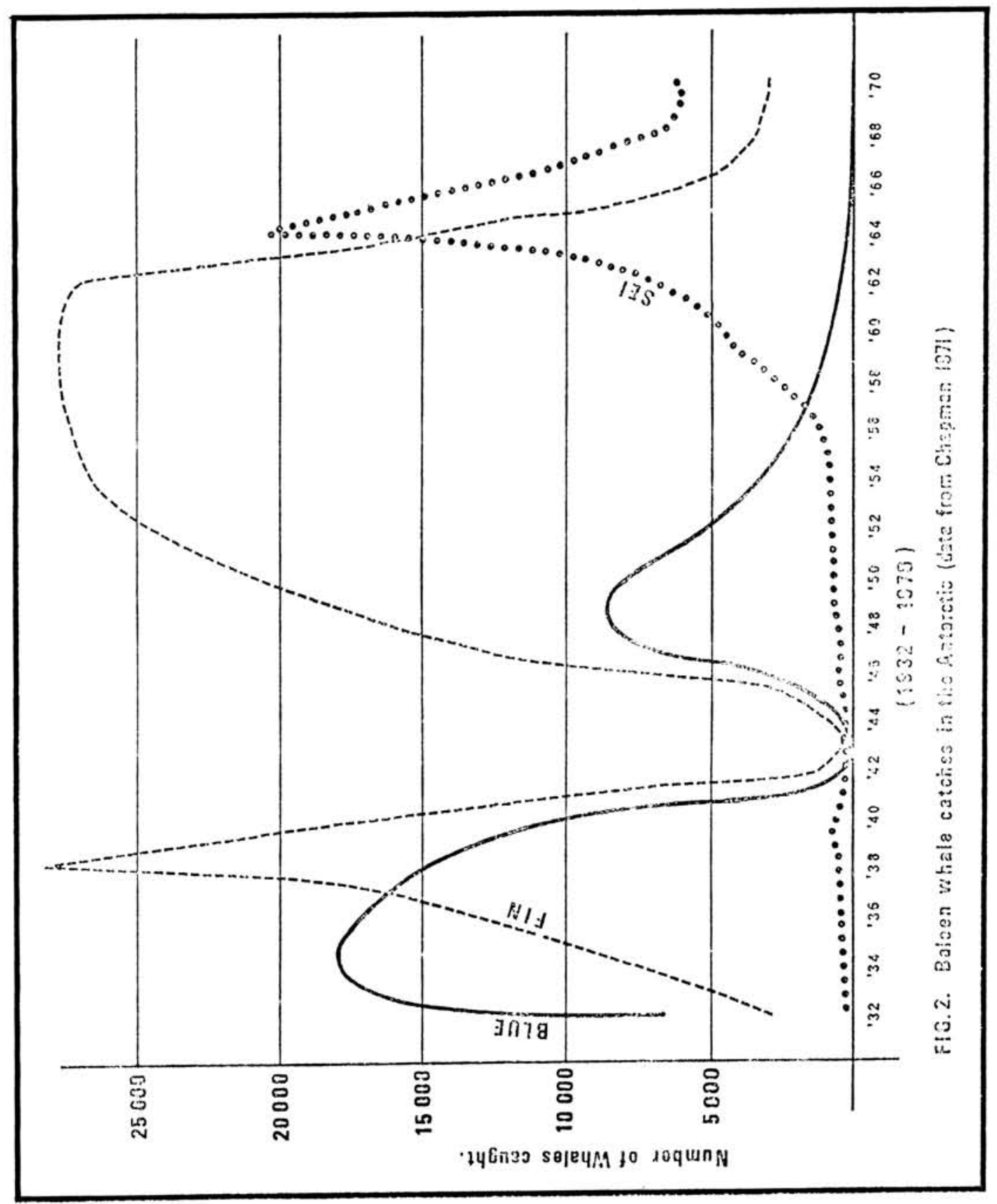


way in which man has over-killed one species after another (Fig. 2). Fortunately species are only exploited until it becomes uneconomical to harvest them, they are then left alone. Unfortunately they have to then fend for themselves in what probably is an unstable environment.

Thirdly, development of coastal towns, roads, industries and resorts have devastating abilities of not only shrinking the available natural coastal environment, but also to change the surrounding areas.

Lastly, there is the relentless destruction caused by uncontrolled tourist activities. These include spear-fishing, shell-collecting, baitcollecting and collection of living specimens. These activities which together, even if they do not exterminate or endanger entire species, may yet cause serious ecological disruptions. Marine turtles are endangered through over-harvest of adults and unlimited collection of eggs and the loss or reduction of suitable nesting areas by the activities of man (Hughes 1976).

\section{Purposes of Marine Parks and Reserves}

An area managed along sound ecological principles is highly significant for man's ultimate understanding of the dynamics of a particular ecosystem. Therefore, an area protected solely for the reason of preserving it in its pristine condition, is relevant to the study of the natural processes, and to the protection of endangered species and habitats from man's parturbations. Reserves have, however, four main purposes, depending on their use (Pollard 1976):

(i) the conservational purpose of marine reserves would imply a sanctuary for the preservation of a commercially exploited species or the protection of a habitat;

(ii) the scientific purpose of marine reserves would be to protect an area in its pristine condition as a reference area or to monitor a disturbed area or manipulate it in order to gain an understanding of the ecosystem;

(iii) the educational purpose of a marine reserve would be the interpretation of the ecology of the area to both students and the general public to instill a general appreciation for the marine conservation;

(iv) the recreational purpose of marine reserves, if managed along sound ecological lines, would not include the entire spectrum of man's enjoyment possibilities. It would only include his more passive recreational activities such as snorkelling, underwater photography, animal watching (birds, whales, dolphins, fish and invertrebrates), or aesthetic values.

\section{Existing Marine Parks and Reserves}

The RSA can only boast with three marine reserves in the sense that they are protected for aesthetic, educational and recreational purposes 
(Fig. 1). Only one of these is spacious enough to have been proclaimed a marine national park.

The Tsitsikama Coastal National Park is a $67 \mathrm{~km}$ stretch of shoreline, mainly rocky, but has a few sandy beaches and numerous riverlets running into the sea. Proclaimed in 1964, this unspoiled rugged coast is administered by the National Parks Board of Trustees (Robinson 1969). It is situated along the south coast and therefore has a wide spectrum of marine life covering warm tropical and subtropical Indo-Pacific and cold Atlantic and sub-Antarctic species. The park extends $0,8 \mathrm{~km}$ out into the sea and everything is protected including flotsam and jetsam, dead trees, pebbles and rocks. Controlled angling is, however, allowed at specific well demarcated places. The objectives for this park are:

(i) the conservation of a south coast marine environment in its pristine state;

(ii) research on an ecosystem orientated basis; and

(iii) marine ecology interpretation and education.

The park is zoned and only half of the coastline is accessible to the public for recreational purposes in the form of hiking, birdwatching, botanising and snorkelling.

The HF Verwoerd Reserve is a small sanctuary close to Cape Town. Although only two kilometres in length, it represents the west coast limit of the south coast, supporting a fine example of a kelp-bed community with huge macrophytes, rock lobsters and perlemoen. The sanctuary is administered by a local authority in co-operation with the Sea Fisheries Branch (Heydorn and Hughes 1969). All marine life, both flora and fauna is protected with the exception that controlled angling is allowed.

The Sardinia Bay Marine Reserve, situated on the eastern limit of the south coast near Port Elizabeth. The sanctuary protects only the marine fauna and does not allow fishing of any kind along its five kilometre shoreline (Grindley 1974). It is important in that it supplements the Tsitsikama National Park in having good representation of the more tropical and sub-tropical south coast species.

The point to stress here is that only the south coast is represented in the above three reserves.

Apart from the above "true" reserves the Sea Fisheries Branch has created an entire system of sanctuaries and protected areas in order to manage the commercially important species. There are exceptions to this as in the case of the Knysna Sea-horse Hippocampus capensis. This system is rather involved and Table 1 is hopefully sufficient to indicate what this protection entails. 
TABLE 1

Existing Marine Reserves and Protected Areas

\begin{tabular}{|c|c|c|c|}
\hline & Protected organisms & $\begin{array}{l}\text { Number of } \\
\text { Areas }\end{array}$ & $\begin{array}{c}\text { Combined } \\
\text { Coastline } \\
\text { nautical } \\
\text { miles }\end{array}$ \\
\hline \multicolumn{4}{|l|}{ 1. National Marine Parks } \\
\hline $\begin{array}{l}\text { Tsitsikama Coastal } \\
\text { National Park }\end{array}$ & $\begin{array}{l}\text { All Marine life (Flora and } \\
\text { fauna) controlled angling } \\
\text { is permitted in a few } \\
\text { specified areas. }\end{array}$ & 1 & 36 \\
\hline \multicolumn{4}{|l|}{ 2. Nature Marine Reserves } \\
\hline i Sardinia Bay Reserve & $\begin{array}{l}\text { All marine fish ("fish" } \\
\text { includes all marine fauna) }\end{array}$ & 1 & 5 \\
\hline $\begin{array}{l}\text { ii H.F. Verwoerd Reserve } \\
\text { (Betty's Bay) }\end{array}$ & $\begin{array}{l}\text { Marine life excluding } \\
\text { angling fish }\end{array}$ & 1 & 2 \\
\hline $\begin{array}{l}\text { iii Buffalo Bay and } \\
\text { Robberg Reserves }\end{array}$ & Bait organisms & 2 & 12 \\
\hline iv Knysna lagoon & $\begin{array}{l}\text { Seahorses, pipefish and } \\
\text { seaweeds }\end{array}$ & 1 & 6 \\
\hline \multicolumn{4}{|l|}{ 3. Guano Islands } \\
\hline $\begin{array}{l}\text { (Government permits re- } \\
\text { quired for admission.) }\end{array}$ & $\begin{array}{l}\text { All marine life and sea- } \\
\text { birds, although seals \& } \\
\text { guano are exploited. }\end{array}$ & $\begin{array}{c}40 \\
\text { (including } \\
\text { islands off } \\
\text { S.W.A. Coast) }\end{array}$ & 40 \\
\hline \multicolumn{4}{|l|}{ 4. Commercial Fish Reserves } \\
\hline $\begin{array}{l}\text { i St. Helena Bay, } \\
\text { Saldanha Bay, Table } \\
\text { Bay and Luderlitz Bay }\end{array}$ & Rock Lobsters & 4 & 47 \\
\hline $\begin{array}{l}\text { ii Palgrave Point to } \\
\text { Kunene River (S.W.A.) }\end{array}$ & Pelagic fish & 1 & 220 \\
\hline $\begin{array}{l}\text { iii Algoa Bay } \\
\text { (Hougham Park) }\end{array}$ & Oysters & 1 & 0,2 \\
\hline \multicolumn{4}{|c|}{ 5. Areas Closed for specific Fishing Gear } \\
\hline i All commercial gear & Perlemoen (abelone) & 1 & 20 \\
\hline ii All nets & All fish & 5 & 36 \\
\hline iii All nets & Sharks & 1 & 200 \\
\hline iv All nets & Yellowtail & 1 & 130 \\
\hline $\begin{array}{l}\text { v Nets except purse } \\
\text { seines }\end{array}$ & All fish & 1 & 11 \\
\hline vi Purse Seine nets & Mullet and pelagic fish & 2 & 115 \\
\hline $\begin{array}{l}\text { vii Trawl nets } \\
\text { (Bottom/Midwater) }\end{array}$ & West Coast rock lobsters & 3 & 1163 \\
\hline $\begin{array}{l}\text { viii Gill nets } \\
\text { (Set/Drift/Staked) }\end{array}$ & All fish & 9 & 645 \\
\hline
\end{tabular}

6. Remarks About sixty species or specific groups of organisms are protected partially or entirely. Completely protected organisms include seafans, dolphins, and six different whale species.

(Information mainly from De Villiers, pers. comm.) 


\section{Proposed Marine Parks and Reserves}

\section{Marine National Parks}

As previously stated the RSA has three distinct coasts, only one of which is represented by the Tsitsikama Coastal National Park. It is therefore desirable that a spacious stretch of coastline be set aside to represent each of the other two coasts.

A Namaqualand Marine National Park, if proclaimed, would represent the cold Benguela current system of the west coast. It should be situated between the Orange River Mouth in the north and the Olifants River in the south. Hopefully the entire coastline could be proclaimed as such. Where private property is adjacent to this coast, the terrestrial boundary will obviously be the high water mark. The coast is dominated by dune and sandveld but representatives of rocky shore and kelp-bed areas should also be included.

A Tongaland Marine National Park has been proposed as a marine reserve by many biologists (Heydorn and Hughes 1969, Grindley 1975) and every effort should be made to establish it as such. It is probably the most beautiful coast along South Africa. Besides preserving the eastcoast in its pristine condition, the nesting area of turtles could be protected (Hughes 1976).

A de Hoop Marine National Park would represent a unique example of the Cape Shores (including its weathered sandstone shores, fish species as well as relevant Cape macchia. As such a likewise addition would imply an excellent contribution to the spectrum of National Parks).

In addition to these, five islands should also be given national status.

A Dassen Island National Park which would represent an excellent example of a west-coast island system with both a rich avi-fauna as well as a rich inter- and subtidal fauna.

A Dyer Island National Park would represent a south-coast island environment with a unique variety of birds visiting the island.

A Seal Island National Park, a small rocky out-crop with a healthy Cape fur-seal Arctocephalus pusillus population situated in Mossel Bay.

A Bird Island National Park (Algoa Bay) A 25 ha island in Algoa Bay supporting a population of some 50000 gannets Sula capensis.

The Marion National Park (Antarctic). If proclaimed it would protect an unique environment. Ecosystem research would be fundamental to its management. 
Fig. 3. PROPOSED MARINE PARKS AND RESERVES IN SOUTH AFRICA

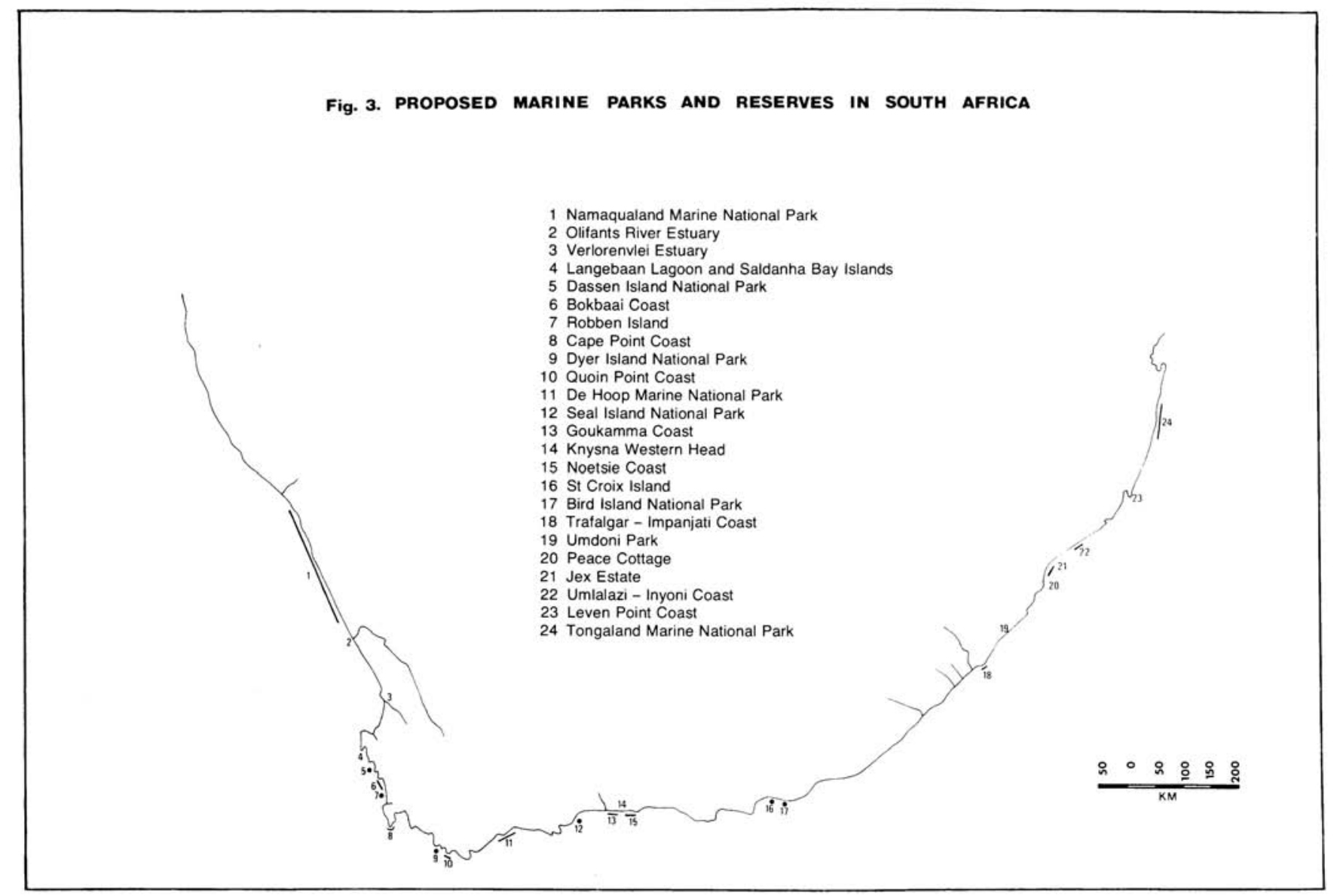




\section{Provincial Marine Parks and Reserves}

The following list are proposed marine reserves and if established will afford endangered marine species and habitats better protection. (This list endorses the list by Grindley 1975).

(a) West Coast (See Fig. 3)

Olifants River Estuary,

Verlorenvlei Estuary,

Langebaan Lagoon and Saldanha Bay Islands,

Bokbaai coast,

Robben Island and

Cape Point coast

(b) South Coast

Quoin point coast,

Goukamma coast,

Knysna Western Head,

Noetsie coast (Eastern Knysna Head to Robberg) and

St. Croix Island

(c) East Coast

(The Ciskei and Transkei coasts have been omitted)

Trafalgar-Impanjate coast,

Umdoni Park,

Peace cottage,

Jex estate,

Umlalazi-Inyone coast and

Leven Point coast.

\section{Conclusion}

If the RSA is to protect its marine environment from the adverse effects of pollution, over-exploitation and habitat destruction, drastic action is needed. The establishment of marine parks and reserves can no longer wait. It is urgent that they be proclaimed immediately.

South Africa has been a leader in terrestrial nature conservation since the establishment of the Kruger National Park. Let us prove that we are not only sympathetic towards marine nature conservation but also develop a rational and practical system for the protection of the marine environment for future generations. 


\section{REFERENCES}

CHAPMAN, D G 1971. Estimation of Population Parameters of Antarctic Baleen Whales. Quantitative Science Paper No. 22. University of Washington. Mineograph.

GOODWIN, A J H 1946. Prehistoric Fishing Methods in South Africa. Antiquity 20: 134-141.

GRINDLEY, J R 1974. The establishment of the Sardinia Bay Marine Reserve. E. Cape Naturalist 54: 2-4

GRINDLEY, J R 1975. The Need for the establishment of marine reserves in South Africa. Proceedings of the Council for the Habitat Symposium on Coastal Conservation. Durban. April.

HEYDORN, A E F, and G R HUGHES. 1969. Urgent Need for more Marine Reserves. Afr. Wildl. 23 (3):270-278

HUGHES, G R 1976. Sea Turtles in South East Africa. Proceedings of a symposium on Endangered Wildlife in Southern Africa. University of Pretoria (81-87). Mineograph.

POLLARD, D A 1976. International Conference on Marine Parks and Reserves, Tokyo, May 1975. Australian Marine Science Bulletin 52: 7-11.

ROBINSON, G A 1969. The Tsitsikama Coastal National Park, South Africa. Biol. Cons. 2 (1): $72-73$. 